\title{
Erratum
}

\section{An Expeditious Synthesis of Nocardiolactone}

Ya-Ping Sun, Yikang Wu* Synlett 2005, 1477.

The chain on the right-hand side of structures $1,5,6,7,8$ and 9 was shown with one carbon less than required; the subscript 11, indicating the repeating methylene unit, should be 12 . The corrected structures are shown here.<smiles>CC(C)CCCC1C(=O)OC(C(C)C)C1C(C)C</smiles>

1<smiles>CO[C@H](C(=O)OCc1ccccc1)C(C)C</smiles>

7<smiles>CC(C)C(C)C(C(=O)N1C(=S)SCC1c1ccccc1)C(C)C</smiles>

5<smiles>CO[C@H](C(=O)O)[C@@H]1CCCCC1C(=O)O</smiles>

8<smiles>CC(C)C1C(O)C(C(=O)O)CC(C)C1C(=O)Br</smiles>

6<smiles>CCCC=CC(C)C</smiles> 